\title{
On the Development of the Sexual Organs and Fertilization in Picea excelsa.
}

BY

K. MIYAKE.

With Plates XVI and XVII.

$\rightarrow+$

INTRODUCTORY.

T $\mathrm{N}$ spite of the activity which has of recent years been 1 manifested in the study of the fertilization and embryogeny of the Abietineae, the genus Picea has been seemingly neglected. In fact, our knowledge on the cytology of the sexual reproduction of Picea remained almost stationary for nearly ten years. In the light of the recent studies on the other members of the Abietineae, it is highly desirable that similar investigations should be made in Picea. It was with this object that the work described in the present paper was undertaken.

But few investigators have hitherto studied the development of the gametophytes and fertilization in Picea. Hofmeister ('51, '58, '62), who made the first careful and extensive studies on the life-history of the Conifers, has only incidentally referred to Picea.

Strasburger ('69) in his first work on the fertilization of the Conifers described the structure of the archegonium and the formation of the proembryo in Picea excelsa (P.vulgaris) with several figures. He traced the pollen-tube into the arche-

[Annals of Botany, Vo1. XVII. No. LXVI. March, 1903.] 


\section{Miyake.-On the Development of the Sexual}

gonium, and affirmed Hofmeister's observation regarding the presence of a closed pit at the apex of the tube. Three years later Strasburger ('72) made a further contribution to the embryology of Picea by describing the process of embryoformation in Picea excelsa.

In 1878 Strasburger observed two 'primordial cells' in the pollen-tube of Picea excelsa, and mentioned that these cells dissolve one after another before fertilization takes place; later, the sperm-nucleus, which, he thought, was formed from the contents of the tube, appears in the upper part of the egg and finally fuses with the egg-nucleus. In his 'Angiospermen und Gymnospermen,' Strasburger ('79) makes the statement that it is the foremost of these two 'primordial cells' in the pollen-tube which becomes active in fertilization. In I 884 , by a study of Picea excelsa, he confirmed Goroschankin's observation ('83) on Pinus as to the passage of both sperm-nuclei into the egg, but pointed out that only the one in advance fuses with the egg-nucleus.

The same author in his work on the pollen of the Gymnosperms ('92), in which he showed that Belajeff's observations ('91) on the development of the pollen-tube in Taxus baccata are in general true for other Gymnosperms, gave the results of observations on the germinating pollen of Picea excelsa. In the mature pollen-grain just before pollination he observed that the third prothallial cell or central cell ${ }^{1}$ has already been divided into the stalk- and generative cells, the two other disintegrating prothallial cells being seen as two slit-like bodies. He also found that the generative cell divides into two sperm-cells before it passes down into the pollen-tube.

In the following year Belajeff ('93), in his second paper on the pollen-tube of the Gymnosperms, described the further development of the pollen-tube in Picea excelsa. According to him the generative cell divides into two sperm-cells before it moves down into the pollen-tube ; the stalk-cell is broken down and only the nucleus follows the sperrm-cells, finally

\footnotetext{
${ }^{1}$ I take the third prothallial cell as homologous to the central cell of the Pteridophytes, and the latter term is used throughout the paper.
} 
overtaking and passing the latter, and is found near the tip of the tube with the vegetative nucleus.

The material for the present studies was collected from three grown-up trees on the campus of Cornell University, during May and June of I90I and 1902. The cones of one tree had smooth oval scales, while those of the other two trees had scales somewhat rhomboidal in shape with wavy margins. The three trees looked almost alike in the shape and size of the leaves, and in general appearance. Histologically, at least so far as the structure of the ovule is concerned, I failed to find out any difference between these two forms. As Picea excelsa is exceedingly variable, presenting a number of varieties and forms, perhaps little importance should be attached to these individual peculiarities ${ }^{1}$.

Flemming's chrom-osmo-acetic acid solution of the stronger concentration was almost entirely used as the fixing fluid. The material was washed, dehydrated, decolorized, and imbedded in paraffin in the usual way. The sections were cut usually from 8 to $\mathrm{I} 2 \mu$ in thickness. For staining, Flemming's safranin, gentian-violet, and orange combination was extensively used. Sometimes this stain was used without safranin and gave some good results.

The present studies were conducted in the Botanical Laboratory of Cornell University, and I wish to express here my best thanks to Professor G. F. Atkinson for his kind advice and helpful criticisms.

\section{Development of the Male Gametophyte.}

In the mature pollen-grain, just before pollination, the central cell is usually divided into the stalk- and generative cells, and the disintegrating remains of the first two prothallial cells can be seen merely as two thin and darkly staining bodies between the stalk-cell and the pollen-wall (P1. XVI, Fig. 6). This fact has already been noticed by Strasburger ('92). According to him Larix behaves in the same way as

1 On the variations of Picea excelsa see Schröter, '98. 
Picea, and differs from Pinus, in which the division of the central cell takes place after pollination.

Fig. I shows a pollen-grain in which the central cell is still undivided. Several stages of the division of the central cell are shown in Figs. 2-5. Figs. I-6 are drawn from sections of the anthers, collected a few days before pollination. In the same anther, or even in a single section, I was often able to find out all the different stages figured here. The stalkand generative cells are almost equal in size and structure when they are formed; they usually contain several nucleoli (Fig. 6). The nucleus of the vegetative or tube-cell is oval or sub-spherical, and is situated very close to the free end of the generative cell. It contains usually two or sometimes more nucleoli (Figs. I-6).

In the neighbourhood of Cornell University, Ithaca, N. Y., pollination takes place during about the second week in May. The dates varies somewhat by seasons. At the time of pollination, the female cone stands erect, the scales being divergent. It is about one-third or one-fourth the length of the mature cone. After about a week or ten days, the scales are closed and the cone begins to droop downward.

The germination of the pollen-grain seems to take place in a few days after pollination. Soon after the formation of the pollen-tube, the tube-nucleus, which has usually a single nucleolus about this time, moves down towards the tip of the tube (Figs. 9, I0); Both the generative and stalk-cells continue to increase in size (Figs. 7-10). The generative cell enlarges more rapidly, and its nucleus soon assumes a more or less spherical shape with a prominent nucleus; its cytoplasm becomes dense and deeply staining (Figs, 9-II). The cytoplasm of the stalk-cell on the contrary assumes a vacuolate character. Its nucleus grows but slightly, and one or more prominent nucleoli, which were observed in its early stage of development, are now replaced by one or several small granules; sometimes one of the granules is slightly larger and seems to represent a true nucleolus (Figs. 7-II).

In the meantime the stalk-cell is detached from the inner 
wall of the pollen-grain, and together with the generative cell moves down into the pollen-tube (Figs. II, I2). Strasburger ('92) states that in Picea excelsa the generative cell divides in the pollen-grain, and of the resulting two cells the one in advance is smaller than the other ${ }^{1}$. Belajeff ('93) also observed in Picea excelsa that the generative cell divides into two before it leaves the pollen-grain, and only the naked nucleus of the stalk-cell enters the pollen-tube. Dixon ('94) made a similar observation in Pinus sylvestris. Miss Ferguson ('01 $a$ ), in her studies on the development of the pollen-tube in several species of Pinus, obtained very different results. She found that the generative cell enters the pollen-tube before it divides, and also demonstrated that the whole stalkcell moves down into the pollen-tube. My observations in Picea agree with Miss Ferguson's in both points.

The generative cell, as it passes into the pollen-tube, is more or less elongated and increases much in size; it has no definite cell-wall, and is somewhat irregular in shape (Fig. I2). The stalk-cell, which is attached to the generative cell at its lower side and more or less surrounded by the cytoplasm of the latter, seems to move down the pollen-tube more rapidly; it passes by the generative cell, and soon afterwards is seen at the lower end of the latter (Figs. I3, I4).

Shortly after this the generative cell divides. The process of the division has not been traced, very carefully, but judging from several division-figures so far observed, I may say that in general it is very much like that of Pinus as studied by Miss Ferguson ('01 $a$ ). The mitotic figure, like Fig. I 5, suggests that the spindle may very likely be unipolar in origin as in Pinus. The cell-plate is formed at the equator of the spindle, but persists only for a short time and finally disappears, as was already noticed by Miss Ferguson in Pimus (Figs. 16-20). Soon after the division the two sperm-nuclei are separated from each other by a considerable distance (Fig. I 7). Gradually

1 ' Bei Picea vulgaris sieht man die grosse Antheridialzelle sich ebenfalls schon im Pollenkorn theilen. Die vordere generative Zelle ist auch bei Picea kleiner als die hintere' (Strasburger, '92, p. 25). 


\section{Miyake.-On the Development of the Sexual}

the two nuclei approach each other, or rather the lower nucleus moves towards the upper one, until they come to lie in the uppermost part of the common cytoplasm (Figs. I 8-2I). The two nuclei are not equal in size, and the upper one seems to be always smaller. This inequality in size could be detected as far back as the formation of the daughter-nuclei (Fig. I6). Miss Ferguson.('01 $a$ ) made a similar observation in Pinus. She also demonstrated the fact that in Pinus two sperm-nuclei are surrounded by the common cytoplasmic mass; two spermcells never being formed as was supposed to be the case by former investigators (Strasburger '92, Belajeff '93, Dixon '94, Coulter '97).

At this time the pollen-tube has reached nearly half way down towards the archegonium. After the formation of the sperm-nuclei the downward growth of the tube is comparatively rapid. The pollen-tube is somewhat sinuous in its course, but I have never observed it to branch, as is often the case in Pinus.

The sperm-nuclei increase in size after they are formed, and present a densely granular appearance under a low power, although these granules seem to be somewhat reticularly arranged under a high power. The nuclei, when mature, often stain intensely, taking the violet in Flemming's triple method. They seem to contain several nucleoli, but the latter are often obscured by the other densely staining structures (Figs. 19-22). Fig. I 5 shows two mature sperm-nuclei near the tip of a pollentube which has reached the lower part of the nucellar cap almost approaching the neck of the archegonium. The stalkcell with its characteristic nucleus is found at the lower end of the sperm-cytoplasm.

The nucleus of the stalk-cell usually takes the violet stain in the triple method. It is very much like one of the nuclei of the nucellar cap both in its size and staining character throughout its entire history in the pollen-tube. Although Miss Ferguson for the first time clearly established the fact that the stalk-cell remains intact throughout its entire history in the pollen-tube, a careful examination of Strasburger, 
Belajeff, and Coulter's drawings ${ }^{1}$ leads me to think that they too saw the entire stalk-cell in the pollen-tube; it was, however, interpreted by them as a mere nucleus.

The tube-nucleus, which is often somewhat irregular in outline and has a prominent nucleolus, is always located near the tip of the pollen-tube (Figs. IO-I6, I 8-2I). This nucleus seems to play an important part in the elongation of the pollen-tube ; it has been observed in Ginkgo (Hirase '98) and Cycads (Ikeno '98, Webber '01) that when the tip of the pollen-tube ceases to grow and the other end of the tube begins to elongate, a little while before fertilization, the tubenucleus migrates to this new growing portion.

The starch-grains, which can usually be observed in the mature pollen-grain, increase much in size and amount after the formation of the pollen-tube. Very often these grains have deeply staining portions, which I have not sketched in my drawings, in their centres. They are probably the cracks or spaces left by the dissolution of some of the starch in the centre of the grain. The starch-grains also appear in the fullgrown stalk-cell shortly before its passing into the pollen-tube ; after the cell has entered the tube starch is no longer visible in it (Fig. II). The stalk-cell with starch-grains was also observed in Zamia by Webber ('01).

\section{Early Development of the Archegonium.}

The archegonium usually develops from a superficial cell at the apex of the female prothallium. When the prothallium reaches a certain size, some of the cells in the uppermost layer cease to divide, but continue to grow, so that they are distinguished from the adjacent cells by their larger size and larger nuclei. These are the initial cells of the archegonia (Figs. 23, 24). While this archegonial initial is only a few times as large as the adjacent cells it divides, giving rise to a small upper cell, the mother-cell of the neck, and a large lower cell, the central cell of the archegonium (Figs. 25, 2.6).

${ }^{1}$ Strasburger '92, Figs. 43, 44 ; Belajeff '93, Fig. 16 ; Coulter' 97 , Fig. 5. 


\section{$35^{8}$ Miyake.-On the Development of the Sexual}

The smaller cell soon divides into two cells by an anticlinal wall; these two cells then divide several times by both anticlinal and periclinal walls and form the neck of the archegonium. The neck of the full-grown archegonium usually consists of four to eight rows of cells, with two to four cells in each row (Figs. 27-36, 4I). Strasburger made a similar observation in 1869 , and stated that the neck consists of two to four tiers of cells.

The rapid growth of the central cell takes place soon after its formation. The cytoplasm presents a very vacuolate appearance in the early stage of development (Figs. 27-3I). But as the central cell continues to grow the cytoplasmic contents become more dense, and the number and size of the vacuoles gradually decrease. When the archegonium reaches its full size only a few small vacuoles are found in the more or less finely granular cytoplasm, and now a few so-called proteid-vacuoles begin to appear (Fig. 32). The nucleus is, from the first, always situated at the apex of the cell just beneath the neck. It has one prominent nucleolus, and sometimes one or two smaller ones may be present (Figs. 26-36). Enveloping the central cell is a layer of cells rich in protoplasm and with large nuclei ; these are the sheath- or wall-cells of the archegonium, and correspond to the follicle-cells of the animal egg in their function. These cells are differentiated from the adjacent endosperm-cells very early in the development of the archegonium.

The number of archegonia in each ovule varies from two to seven, the most common number being four. Of over four hundred ovules studied, I kept an account of the number of archegonia in about three hundred of them, and found that about one-half had four archegonia; about one-fourth had three, and about one-fifth had five archegonia, while eight cases were met in which each ovule contained six archegonia. In four cases an ovule was found with two archegonia, and but a single ovule with seven archegonia was met with. This agrees in the main with the observation of Strasburger ('69), who found three to five archegonia in each ovule of Picea excelsa. 


\section{Formation of the Ventral Canal-Cell.}

As the central cell prepares for division the deeply staining substance, which is coarsely granular, accumulates near the centre of the nuclear cavity, in a condition suggesting synapsis, similar to that observed by Murrill ('00) in Tsuga. Soon there appears, along the lower side of the nucleus, a clear court which at first assumes a crescent shape in section, and later approaches to a conical form. Sooner or later delicate fibres make their appearance inside the court; similar fibres also appear on the upper side of the nucleus. These fibres seem to represent the beginning of an extra-nuclear spindle. At the same time the upper and lower sides of the nucleus become more or less irregularly indented (P1. XVII, Figs. 37, 38). The fibres seem to press the nuclear membrane from both sides, and finally to enter the nuclear cavity by the dissolving away of the membrane, which first takes place where the fibres are attached. Fig. 39 shows a stage in which the nuclear membrane is still intact, except the side close to the fibres where it is beginning to disappear. Chromosomes about twelve in number are found inside the nuclear cavity.

The spindle, when fully formed, is more or less pointed at the lower end and somewhat blunt on the upper side. It seems to lie wholly within the boundary of the original nucleus, so that one who had not seen the earlier stages of division might interpret the origin of the spindle as intranuclear (Figs. 40-43). The various stages of the division are shown in Figs. 37-48. The two daughter-nuclei are considerably different in size when they are formed, the nucleus of the egg being several times larger than that of the ventral canal-cell. The process of division is in the main similar to Pinus as described by Miss Ferguson ('01 $b$ ); the only noticeable difference is that no accumulation of chromatic substance has been observed in the early stage of division in Pinus. No trace of the dense fibrous mass beneath the 


\section{Miyake.-On the Development of the Sexual}

nucleus, from which the lower spindle arises, as described in Tsuga by Murrill ('00), has been observed in Picea.

The ventral canal-cell shows signs of disintegration very soon after its formation. The nuclear membrane seems to break down very soon, and the nuclear substance becomes scattered throughout the cell. In the mature archegonium ready for fertilization, the ventral canal-cell usually appears as a lenticular or crescent-shaped cap-over the top of the egg, with a deeply stained mass of granular substance; and a distinct nucleus is no longer visible in it (Figs. 34, 35, 48). In a few cases a fibrous structure, as observed by Blackman ('98) in Pimus sylvestris, was found in the ventral canalcell of Picea. It may probably represent the remains of the spindle-fibres, as suggested by Blackman.

In several preparations showing the division of the central cell, I was able to count the number of chromosomes, and twelve, or approximately twelve, were always found, as already noticed by Blackman ('98) and Miss Ferguson ('01 $b$ ) in Pimus, instead of eight as counted by Dixon ('94). The number of chromosomes in the dividing nuclei of the sheathcells and other cells of the female prothallium has always been found to be approximately twelve, as already found to be the case in Pinus by Blackman ('98), Chamberlain ('99) and Miss Ferguson ('O0 b), while their number in the cells of the nucellus was invariably more than twenty, the actual number being very likely twenty-four.

\section{Maturation of THE EGG.}

The egg-nucleus, soon after it is formed, begins to increase in size, becoming considerably enlarged before the disappearance of the spindle-fibres (Figs. 47, 48). As the nucleus moves down towards the centre of the egg, it continues to enlarge until the centre is reached (Figs. 34, 35). After the division of the central cell, the few vacuoles, if there are any, in the cytoplasm gradually disappear, and at the same time an increase in the number of proteid-vacuoles takes place. Each proteid-vacuole at first contains a number of granules 
often differing in size, and these granules then seem to unite into one or more larger ones. At a later stage, about the time of fertilization, the proteid-vacuoles, each with a single large granule occupying the larger part of the vacuole, are often observed. In addition to the proteid-vacuoles several granules varying in size can be seen scattered all through the egg-cytoplasm. Thus the egg-cytoplasm, which appeared to be finely granular before the formation of the ventral canalcell, presents a much coarser structure about the time of fertilization (Figs. 33-35, 49-5I).

The origin of the proteid-vacuoles is not at all clear, although there is no doubt about their being a kind of nutritive substance. Hirase ('95) observed that the granules in the egg of Ginkgo were of nucleolar origin, being derived both from the nucleus of the central cell and from the nuclei of the sheath-cells. Arnoldi ('00 a) thought that substantially the same thing takes place in Cephalotaxus. Ikeno ('98) observed the passing in of the substance secreted by the nuclei of the sheath-cells, through the numerous pores in the wall of the archegonium, into the egg, and he ascribed to this substance the origin of the proteid-vacuoles. Arnoldi ('00 b) described a remarkable migration of whole nuclei from the sheath-cells into the egg in several species of Pinus. Murrill ('00) and Miss Ferguson ('01 $b$ ) have both failed to find such passage of nuclear substance from the sheath-cells into the egg. In careful examination of numerous archegonia in all stages of development, I was not able to find even a single case representing such a passage in Picea.

The mature egg-nucleus, situated at or near the centre of the archegonium, usually contains one or more large nucleoli and often several smaller ones; but it is not always easy to distinguish the latter from the chromatic granules in the nuclear reticulum. The reticulum presents a more or less granular appearance and stains violet with the triple stain. The nucleus is usually somewhat oval or elliptical in shape, its average size being $100 \mu$ by $\mathrm{I} 20 \mu$ (Figs. 35, $49-5$ I). 


\section{Fertilization.}

The date of fertilization varies for the same and different trees much as pollination does. In I $90 \mathrm{I}$ the earliest date for fertilization was June $\mathbf{I} 5$, while in the same tree the conjugating nuclei were observed as early as June 7 in the following year, the process being apparently most active on the 9 th or Ioth. The difference may largely be ascribed to the unusually early season in 1902, and the condition in I90 I may probably represent that of the normal year. Generally speaking, we may say that in the neighbourhood of Cornell University the fertilization of Picea excelsa takes place about the middle of $\cdot$ June.

The egg seems to be fertilized about five days or a week after the formation of the ventral canal-cell. The pollen-tube reaches the egg by penetrating the neck of the archegonium, and nearly the whole contents of the lower part of the tube, including the two sperm-nuclei, pass into the egg.

In the mature egg which is ready for fertilization, a vacuole was often observed just beneath the neck. Sometimes a few smaller vacuoles may also be present near the larger one. Miss Ferguson's suggestion about the similar vacuole in Pimus Strobus is very instructive; she says that 'this opening in the cytoplasm represents the last act of the egg in its preparation for the reception of the sperm-nucleus.' But I am not quite ready to accept her interpretation without making more careful and extensive observations. The vacuole was sometimes observed in the egg after fertilization (Figs. $5^{1}, 5^{2}$ ).

The larger sperm-nucleus immediately moves down towards the nucleus of the egg. There is no evidence that the spermnucleus increases in size after entering, as was supposed to be the case by some investigators (Coulter '97). The spermnucleus is much smaller than the one figured by Strasburger ('84a), being about one-third the diameter of the egg-nucleus. The sperm-nucleus first comes in contact with the eggnucleus and soon begins to press itself against the latter. Thus the sperm-nucleus becomes more or less imbedded 


\section{Organs and Fertilization in Picea excelsa. 363}

in the substance of the egg-nucleus; but the walls of both nuclei are still intact (Figs. 49-5I). Later stages in the conjugation of the sexual nuclei have not been observed. The fate of the second sperm-nucleus, tube-nucleus, and stalk-cell after their entrance into the egg has not been followed in the present studies.

\section{Division of the Fertilized NuCleus and Formation of THE PROEMBRyo.}

The fertilized nucleus soon divides into two smaller nuclei. The karyokinetic spindle of this division is shown in Fig. 52. The two daughter-nuclei thus formed increase rapidly in size, and then divide simultaneously. The four free nuclei soon increase in size. When they have reached their full size, they begin to move down toward the base of the egg (Figs. 53, 54). Upon reaching the base of the egg, the four nuclei arrange themselves in a plane, and they are surrounded by a deeply staining mass of protoplasm, which is much more finely granular in structure compared with that of the rest of the egg (Fig. 55).

The four nuclei then divide simultaneously in a plane transverse to the long axis of the egg (Fig. 56). After the complete formation of eight daughter-nuclei walls are formed between them, and a tier of four completely walled cells is cut off below, the upper four nuclei still being freely exposed above to the partially segmented cytoplasm of the egg (Fig. 57). Strasburger ('84, $b$ ) figures the formation of the complete wall in the four-celled stage in Picea excelsa, and the figure is repeated in his later publications ('97, '02). Blackman ('98) also describes, in Pimus sylvestris, the formation of walls between the four nuclei. According to him, 'the two walls are formed at right angles to one another and to the base of the oosphere; each nucleus thus lies at the bottom of a kind of shaft which is open above.' Miss Ferguson ('00 $b$ ) failed to find any sign of wall-formation in the four-nuclei stage, and mentions that 'in the five species of Pines which $\mathrm{B}$ b 2 


\section{Miyake.-On the Development of the Sexual}

I have studied, cell-walls do not arise until after eight nuclei have been formed.'

Strasburger(' $84 b$ ), describing the later process of proembryoformation, states that the lower four of the eight cells divide, and the process is again repeated by the lowest four; thus finally there are three tiers of four cells each, with four free nuclei above them ${ }^{1}$. Coulter and Chamberlain ('01) give a similar description of the corresponding process in Pinus Laricio: "The cells of the single completely walled tier then divide simultaneously, and two tiers are organized. The process is again repeated by the lower tier, and the result is three tiers of four cells each.'

The result of my observations is somewhat different from the above-mentioned process, which seems to be generally accepted. According to my observations, at first, the four nuclei of the upper incompletely walled cells divide simultaneously, and another tier of completely walled cells is formed right above the lower tier (Fig. 58). Then the division is undertaken by the cells of the lowest tier and the formation of the proembryo is accomplished (Fig. 59) ${ }^{2}$. At this stage, therefore, there are four tiers of cells, of four cells each, the upper tier being incomplete since the nuclei are separated from one another by walls, but freely exposed above to the food supply of the egg.

\section{AbNoRmal ARCHEgONIA.}

Several abnormal archegonia have been observed in the course of the present investigations. The archegonium without a neck was often noticed (Figs. 60-61). This neckless archegonium has probably been originated from a cell below

1 'Die das Ende des Eies einnehmenden vier Zellkerne theilen sich in derselben Richtung weiter und die dem Ei-ende näheren wiederholen noch einmal die Theilung. So finden wir schliesslich in dem vom Halstheile abgekehrten Ende des Eies drei Etagen von je vier Zellen und über diesen im Eikörper vier freie Zellkerne' (Strasburger '84 b, p. 483).

${ }^{2}$ According to Miss Ferguson's unpublished observation, which was kindly submitted to me, the process of proembryo formation of Pinus agrees with my result in Picea. 
the superficial layer of the prothallium. In one of them the ventral canal-cell was found at the side of the egg, instead of the top (Fig. 6I). Two archegonia, lying one above the other, were observed several times, and both archegonia were found to be somewhat smaller than the normal one. The lower archegonium, which is usually larger than the upper one, has no neck-cells, but the ventral canal-cell is usually formed.

Fig. 62 shows a double archegonium, in both parts of which the central cell is still undivided. The division of the central cell does not always take place simultaneously. In Fig. 63 the nucleus of the lower archegonium is dividing while that of the upper one remains still undivided. A later stage is shown in Fig. 64 ; the nuclei of both archegonia are already divided and each egg-nucleus is approaching the centre of the egg. The disorganizing ventral canal-cell, which is somewhat lenticular in shape, is seen on the upper left-hand corner of the lower archegonium; that of the upper archegonium is found in another section, and is not sketched here.

\section{SUMMARY.}

r. The mature pollen-grain contains the large tube-cell, two smaller generative and stalk-cells, besides two disintegrating prothallial cells. The third prothallial cell or central cell divides into the stalk and generative cells before pollination, as already described by Strasburger. This division seems to take place within a few days before pollination.

2. Pollination takes place, in the vicinity of Ithaca, N.Y., about the second week in May. The pollen-grain germinates in a few days after pollination.

3. Soon after the formation of the pollen-tube, the tubenucleus leaves the grain, and is found near the tip of the tube. The generative and stalk-cells, which are nearly equal in size and structure when first formed, begin to increase in size, and soon the two cells present very different appearances. The generative cell enlarges more rapidly, and its nucleus assumes a more or less spherical shape with a prominent nucleolus, its 


\section{Miyake.-On the Development of the Sexual}

cytoplasm being very dense and finely granular, while the stalk-cell has a smaller nucleus and very vacuolate cytoplasm.

4. About two weeks, or a little more after pollination, the generative cell followed by the stalk-cell moves down into the pollen-tube. The stalk-cell soon passes the generative cell and attaches itself to the lower side of the latter.

5. The generative cell, after passing into the pollen-tube, is more or less elongated and somewhat irregular in its outline. It has no well-defined cell-wall, and the nucleus occupies at the time of its division the upper part of the dense protoplasmic body.

6. The division of the generative cell has not been followed in detail. The process seems to be very similar to that of Pinus, as studied by Miss Ferguson. The cell-plate formed at the equator of the spindle later disappears, and two sperm-nuclei, which are unequal in size, remain surrounded by a common mass of cytoplasm.

7. The sperm-nuclei, which are separated by a considerable distance when they are formed, soon come to lie together in the uppermost part of their cytoplasm, and early attain their full size, the lower one being always larger.

8. The archegonium usually originates as a single superficial cell in the micropylar end of the female prothallium. Very early in its development it divides into two cells; the upper smaller one forms the mother-cell of the neck and the lower larger one develops into the egg-cell.

9. The number of archegonia in each prothallium varies from two to seven, the most usual number being four; three and five are the next common numbers; six is less common, while two and seven are extremely rare.

10. The central cell is at first very vacuolate, and its nucleus always remains close beneath the neck-cells. Later, its protoplasmic contents gradually increase, and the vacuoles begin to disappear. When the central cell is fully developed and its nucleus is ready for division, the number and size of the vacuoles become very much decreased, while a few proteid-vacuoles begin to appear in the cytoplasm. 
II. In the division of the central cell the spindle-fibres first arise from a clear court along the lower side of the nucleus and grow into the nuclear cavity where they are joined by the fibres from the small upper pole, which also originates outside of the nucleus but without any special court. The spindle, when fully formed, is more or less pointed at the lower end and somewhat blunt on the upper side.

12. The nucleus of the ventral canal-cell when it is formed is much smaller than that of the egg, and very soon shows signs of disintegration. The ventral canal-cell rarely presents the appearance of a normal cell ; at the time of fertilization it may usually be seen as a small somewhat lenticular or crescent-shaped, deeply staining body, just beneath the neck-cells.

I3. The egg-nucleus, soon after it is formed, begins to increase in size, and moves down towards the centre of the egg. The mature egg-nucleus is more or less oval or elliptical in shape, and presents a deeply staining somewhat interrupted reticulum; its average size is about $100 \mu \times 120 \mu$. When the ventral canal-cell is cut off, the vacuoles have nearly disappeared from the cytoplasm of the egg, and the proteid-vacuoles become numerous and prominent. About the time of fertilization the egg-cytoplasm presents a more coarsely granular structure.

14. At the time of fertilization, the greater part of the contents of the pollen-tube including the two sperm-nuclei are discharged into the egg. The larger sperm-nucleus soon moves down and conjugates with the egg-nucleus. The sperm-nucleus first imbeds itself in the side of the egg-nucleus, and both nuclei retain their membranes intact for some time. The further changes in the conjugating nuclei have not been followed. The second sperm-nucleus remains unchanged in the upper part of the egg for some time, and probably disintegrates there finally. The fate of the stalk-cell and the tube-nucleus has not been followed.

15. The fertilized nucleus soon divides into two smaller nuclei. These two nuclei then divide simultaneously, and the four resulting free nuclei soon attain full size and move down 
to the base of the archegonium. No wall is formed between these four nuclei, as supposed to be the case by some previous investigators.

I6. The four free nuclei at the base of the archegonium divide simultaneously. After eight nuclei are completely formed, the walls are laid down between them, as in the case of Pinus described by Miss Ferguson.

I7. The upper four nuclei now divide, instead of the lower four as described by previous investigators, and then follows the division in the four cells of the lowest tier. The proembryo thus formed consists of three complete tiers of four cells each, and the tier of four nuclei which are separated from one another by walls but freely exposed above towards the main mass of the egg-cytoplasm.

I8. Among several abnormal archegonia observed, the archegonium without neck-cells was often noticed. In one of them the ventral canal-cell was seen at the side instead of at the top of the egg. Double archegonia, one archegonium lying above the other, were observed several times. The lower one, which is usually somewhat larger than the upper one, has no neck-cells, while the formation of the ventral canal-cell usually takes place in both of them. 


\section{Organs and Fertilization in Picea excelsa. 369}

\section{Literature Cited.}

ARnoldi, W. ( $00 a)$ : Beiträge zur Morphologie der Gymnospermen, III. Embryogenie von Cephalotaxus Fortunei. Flora, Bd. lxxxvii, pp. 46-63, Taf. I-III, I 900.

- ('00 b): Beiträge zur Morphologie der Gymnospermen, IV. Was sind die 'Keimbläschen' oder Hofmeisters-körperchen in der Eizelle der Abietineen? Flora, Bd. 1xxxvii, pp. I94-204, Taf. VI, I900.

Belajeff, W. ('91): Zur Lehre von dem Pollenschlauche der Gymnospermen. Ber. d. deutsch. bot. Gesell., Bd. ix, pp. 280-287, Taf. 18, I89I.

('93): Zur Lehre von dem Pollenschlauche der Gymnospermen (Zweite Mittheilung). Ber. d. deutsch. bot. Gesell., Bd. xi, pp. I 96-20I, Taf. I2, I893.

Blackman, V. H. ('98): On the cytological Features of Fertilization and related Phenomena in Pinus sylvestris, L. Phil. Trans. Roy. Soc., London, B, vol. cxc, pp. 395-426, Pl. XII-XIV, I898.

Chamberlain, C. J. ('99): Oogenesis in Pinus Laricio; with remarks on Fertilization and Embryology. Bot. Gaz., vol. xxvii, pp. 268-280, Pl. IV-VI, I899.

Coulter, J. M. ('97): Notes on the Fertilization and Embryogeny of Conifers. Bot. Gaz., vol. xxiii, pp. 40-43, Pl. VI, 1897.

Coulter, J. M., and Chamberlain, C. J. ('01) : Morphology of Spermatophytes. Part I. New York, 1900.

Dixon, H. H. ('94) : Fertilization of Pinus sylvestris. Ann. Bot., vol. viii, pp. 2 I-34, Pl. III--V, I894.

Ferguson, Margaret C. ('01 $a$ ): The Development of the Pollen-tube and the Division of the Generative Nucleus in certain Species of Pines. Ann. Bot., vol. xv, pp. 193-223, Pl. XII-XIV, r 1901 .

('01 b): The Development of the Egg and Fertilization in Pinus Strobus. Ann. Bot., vol. xv, pp. 435-479, Pl. XXIII-XXV, I90I.

Goroschankin, J. ('83): Ueber den Befruchtungsprocess bei Pinus pumilio. 4 pp. Strasburg, 1883 .

Hirase, S. ('95): Études sur la fécondation et l'embryogénie du Ginkgo biloba. Journ. Coll. Sc. Imp. Univ. Tokyo, vol. viii, pp. 3०7-322, Pl. XXXIXXXII, 1895 .

Hofmeister, W. ('51) : Vergleichende Untersuchungen der Keimung, Entfaltung und Fruchtbildung höherer Kryptogamen und der Samenbildung der Coniferen. Leipzig, 1851 .

('58) : Neuere Beobachtungen über Embryobildung der Phanerogamen. Jahrb. f. wiss. Bot., Bd. i, pp. 82-I86, Taf. VII-X, I858.

('62): On the Germination, Development, and Fructification of the Higher Cryptogamia and on the Fructification of the Coniferae (English Translation). London, 1862.

IKENo, S. ('98): Untersuchungen über die Entwickelung der Geschlechtsorgane und den Vorgang der Befruchtung bei Cycas revoluta. Jahrb. $\mathrm{f}$ wiss. Bot., Bd. xxxii, pp. 557-602, Taf. VIII-X, I898. 


\section{Miyake.-On the Development of the Sexual}

Murrill, W. A. ('00): The Development of the Archegonium and Fertilization in the Hemlock Spruce (Tsuga canadensis). Ann. Bot., vol. xiv, pp. $583-607, \mathrm{Pl}$. XXXI, XXXII, I900.

Schröter, C. ('98): Ueber die Vielgestaltigkeit der Fichte (Picea excelsa). Separatabdruck aus der Vierteljahrsschrift der Naturforsch.-Gesell. in Zürich, Jahrg. xliii, Hefte 2 und 3, I 30 pp., I 898.

Strasburger, E. ('69): Die Befruchtung bei den Coniferen. Jena, i869. ('72) Die Coniferen und die Gnetaceen. Jena, 1869. ('78) : Die Befruchtung und Zelltheilung. Jena, I878. ('79): Die Angiospermen und die Gymnospermen. Jena, 1879. ('84 a): Neue Untersuchungen über den Befruchtungsvorgang bei den Phanerogamen, \&c. Jena, I 884 . $(' 84 b)$ : Das botanische Practicum. Jena, I 884 . ('92): Ueber das Verhalten des Pollens und die Befruchtungsvorgänge bei den Gymnospermen. Hist. Beitr., Bd. iv, pp. I-46, I892. ('97): Das botanische Practicum. Dritte Auflage. Jena, I897.

Strasburger, Noll, Schenk, Schimper ('02): Lehrbuch der Botanik. Fünfte Auf lage. Jena, Igoo.

Webber, H. J. ('01): Spermatogenesis and Fecundation of Zamia. Bureau of Plant Industry, United States Department of Agriculture. Bull. No. 2, $9^{2}$ pp., Pl. I-VI, I 90 I. 


\section{EXPLANATION OF FIGURES IN PLATES XVI AND XVII.}

Illustrating Dr. Miyake's paper on Picea excelsa.

All figures were drawn with the aid of a camera lucida, using Zeiss's and Bausch and Lomb's microscopes. The abbreviations used are: g.c., generative cell; s.c., stalk-cell; t.n., tube-nucleus; s.p. ${ }^{1}$, first sperm-nucleus ; s.p. ${ }^{2}$, second spermnucleus ; v.c.c., ventral canal-cell ; e.n., egg-nucleus.

\section{PLATE XVI.}

Figs. I-6. Pollen-grains in different stages of development, a few days before pollination. Fig. I. The central cell is still undivided. Figs. 2-5. Various stages in the division of the central cell. Fig. 6. A stage after the division of the central cell. $\not p$., disintegrating prothallial cells ; c.c., central cell. $\times 250$.

Fig. 7. A pollen-grain about to germinate. $\times 250$.

Fig. 8. The same, later stage. $\quad \times 250$.

Fig. 9. A pollen-grain soon after germination; the tube-nucleus is just moving down the pollen-tube. $\times 25^{\circ}$.

Fig. I0. A later stage; the generative cell is considerably enlarged, and the tube-nucleus is found near the tip of the pollen-tube. $\times 25^{\circ}$.

Fig. II. Upper portion of a germinating pollen-grain, a little before the passage of the stalk- and generative cells into the pollen-tube. Starch-grains are found in the stalk-cell. $\times 250$.

Fig. I2. A later stage; showing the passage of the stalk- and generative cells into the pollen-tube. $\times 250$.

Figs. I 3, I4. Later stages than in the above; the stalk-cell has already passed over the generative cell, and is found at the lower side of the latter. $\times 250$.

Fig. I5. Division of the generative cell. $\times 25^{0}$.

Fig. I6. The sperm-nuclei just after their formation; the spindle with a cellplate is seen between them. $\times 250$.

Fig. 17. Similar stage, but little later; two nuclei are much more separated. The remnants of the spindle are seen near the upper nucleus. $\times 25^{\circ}$.

Fig. 18. The two sperm-nuclei are approaching each other; remains of the spindle are still seen. $\times 250$.

Figs. 19-2I. The sperm-nuclei after all traces of the spindle have disappeared, lying in the upper part of their cytoplasm. $\times 250$.

Fig. 22. The full-grown sperm-nuclei near the tip of the pollen-tube; the tube is almost approaching the archegonium. $\times 25^{\circ}$.

Fig. 23. An archegonial initial. $x$ I I0.

Fig. 24. The same, later stage; the nucleus is preparing to divide, being in the spireme stage. $\times$ I I0.

Fig. 25. Nucleus of the archegonial initial is just dividing. $\times$ I IO.

Fig. 26. After the division; the larger central cell and the smaller mother-cell of the neck are formed. $x$ IIO.

Figs. 27-31. Later stages in the development of the archegonium. Fig. 3I 


\section{Miyake.-On Fertilization in Picea excelsa.}

represents an archegonium which has nearly approached to its full size, but its cytoplasm is still quite vacuolate. $\times$ I IO.

Fig. 32. A still later stage, little before the division of the central cell. $\times$ IIo.

Fig. 33. An archegonium showing the division of the central cell. $\times$ I IO.

Fig. 34. An archegonium just after cutting off the ventral canal-cell.

Fig. 35. Mature archegonium; the ventral canal-cell is shown right below the neck-cells. $\times$ I I 0 .

Fig. 36. Upper portion of an archegonium, showing the nucleus of the central cell shortly before division. $\times 500$.

\section{PLATE XVII.}

Fig. 37. Nucleus of the central cell preparing to divide. $\times 500$.

Fig. 38 . The same, later stage; a rupture in the upper right-hand corner of the nucleus was probably made during preparation of the section. $\times 500$.

Figs. 39-45. Various stages of the division to form the ventral canal-cell. $\times 500$.

Figs. 46, 47. Formation of the two daughter-nuclei. $\times 500$.

Fig. 48. Early stage in the development of the egg-nucleus, showing also the disorganizing ventral canal-cell. $\times 500$.

Fig. 49. Entire egg-cell, showing the first sperm-nucleus approaching the eggnucleus. The second sperm-nucleus, which is located near the top of the egg, is found in other section. $\times$ IIO.

Fig. 50. A later stage, showing the first sperm-nucleus just coming into contact with the egg-nucleus. The second sperm-nucleus is found in other section near the top of the egg. $\times$ I IO.

Fig. 5I. A still later stage; the first sperm-nucleus has partly imbedded itself in the egg-nucleus. The second sperm-nucleus is found in the upper portion of the egg. $\times$ IIO.

Fig. 52. The spindle of the first segmentation. $\times$ r 10 .

Fig. 53. The two daughter-nuclei resulting from the first segmentation. $\times$ IIO.

Fig. 54. A later stage, with the four segmentation-nuclei. One of the nuclei is not shown in this figure, being found in other section. $\times$ I IO.

Fig. 55. The four free nuclei at the base of the archegonium; only two of them are shown here. $\times$ I IO.

Fig. 56. Basal portion of an archegonium; the four nuclei are dividing. $\times$ IIO.

Fig. 57. A later stage, showing the eight nuclei of the proembryo; the walls are laid down between the nuclei. $\times$ IIO.

Fig. 58. A still later stage, showing the division of the nuclei of the upper incompletely walled cells. $\times$ I 10.

Fig. 59. Formation of the proembryo is nearly completed; the nuclei of the lower tiers are in the late telophase of division. $\times$ I 10.

Figs. 60-64. Abnormal archegonia. Figs. 60, 6r. Archegonia without neckcells; in Fig. 6r the ventral canal-cell is formed at the side of the egg instead of the top. Figs. 62-64. Double archegonia in various stages of development. $x$ IIo. 
Annals of Botany.
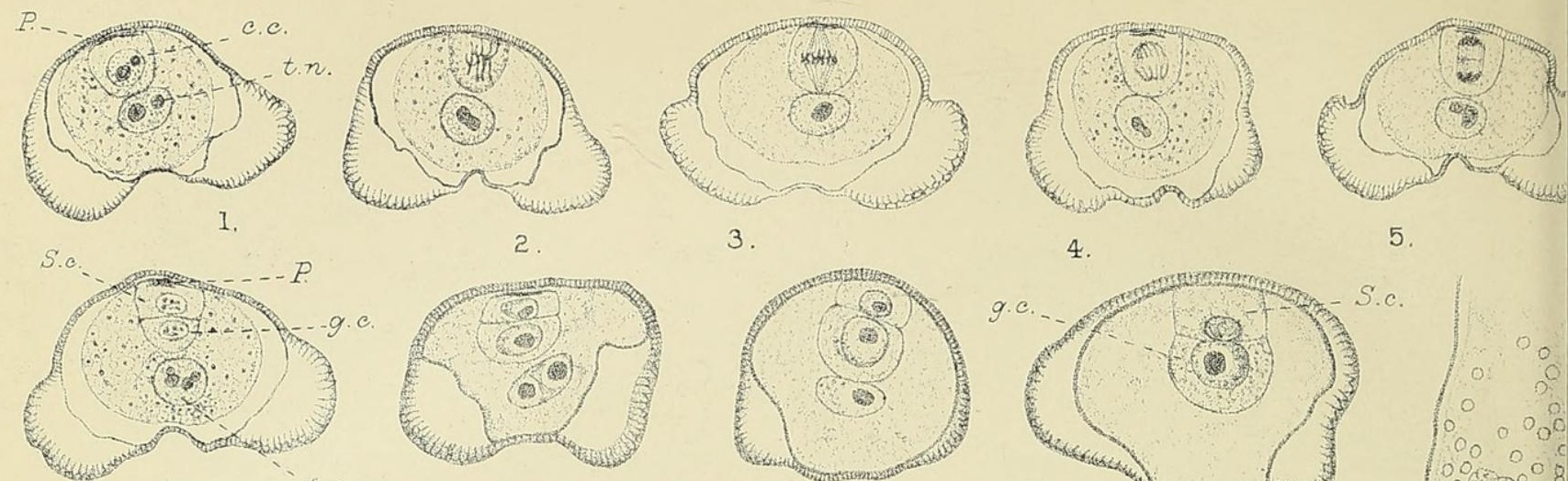

6.

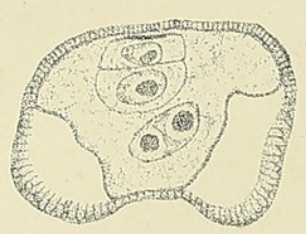

7.

3.

4.

5.

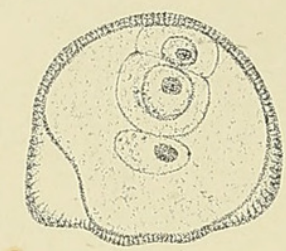

8.
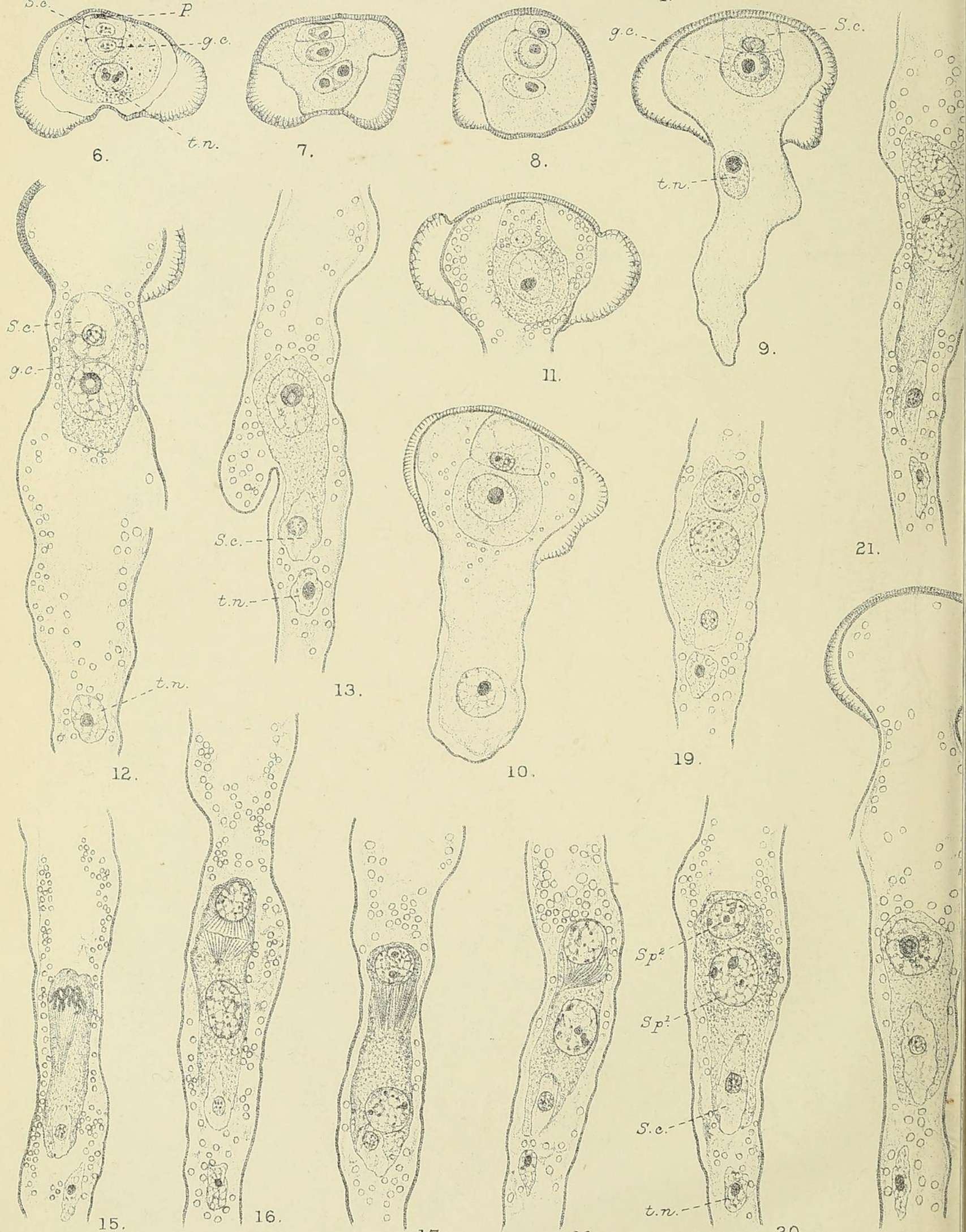

K. Miy ake, del.
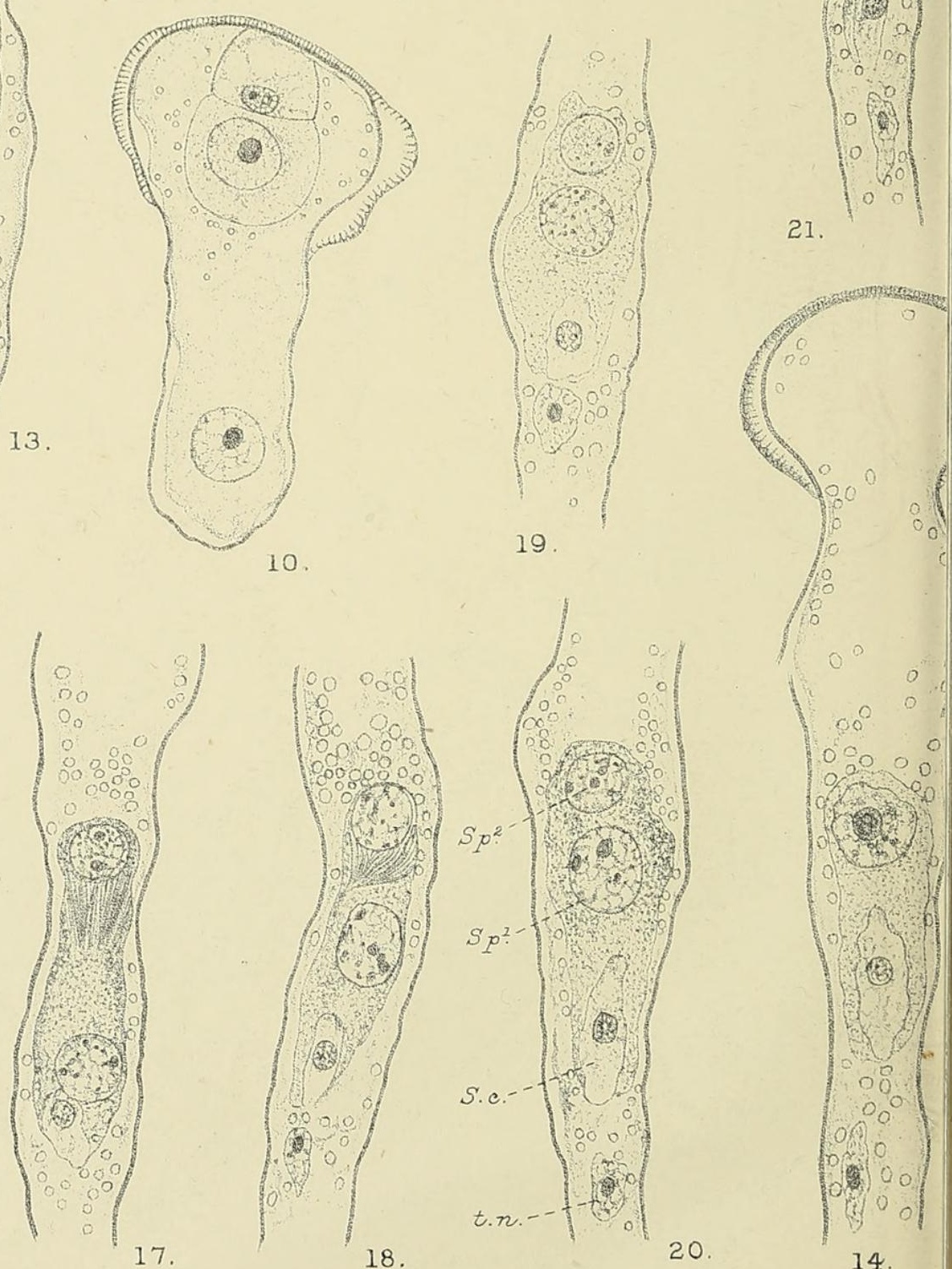

17.

18.

20

MIYAKE.- PICEA EXCELSA. 
Vol.XVII,PL.XVI.

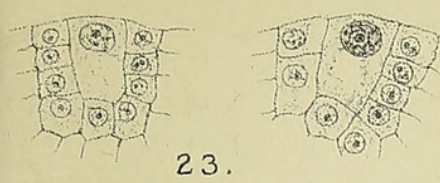

24.

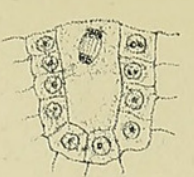

25.

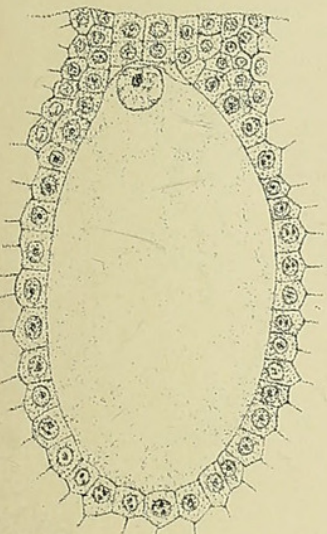

29.

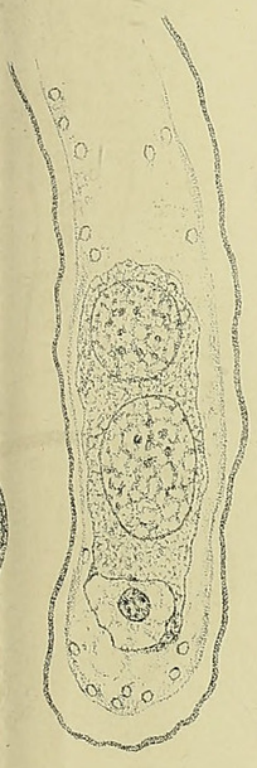

22.

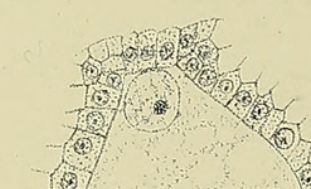

:

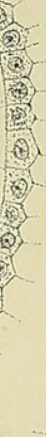

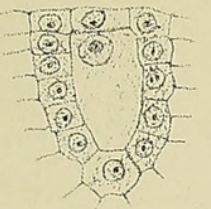

26.

(1)

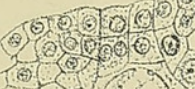

(3).

(1) (19)

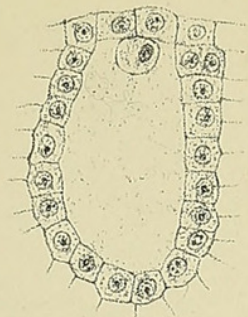

27.

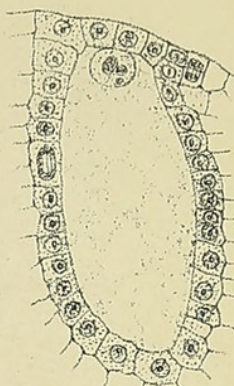

28

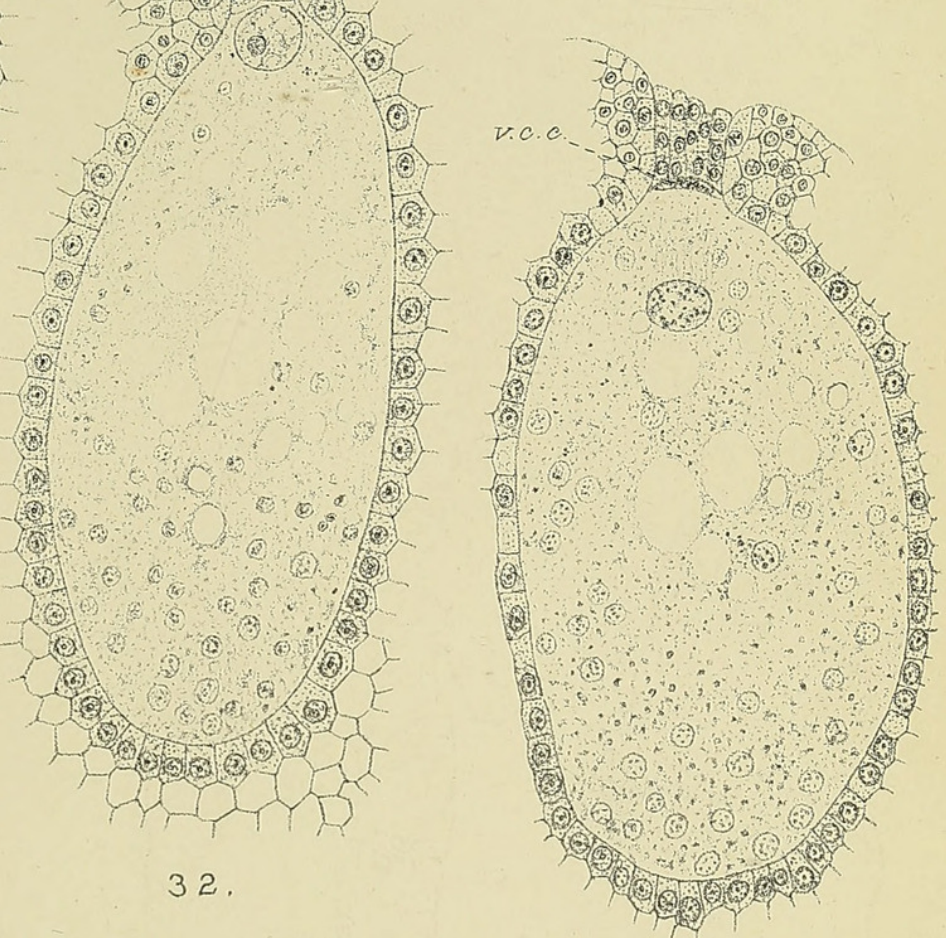

34.
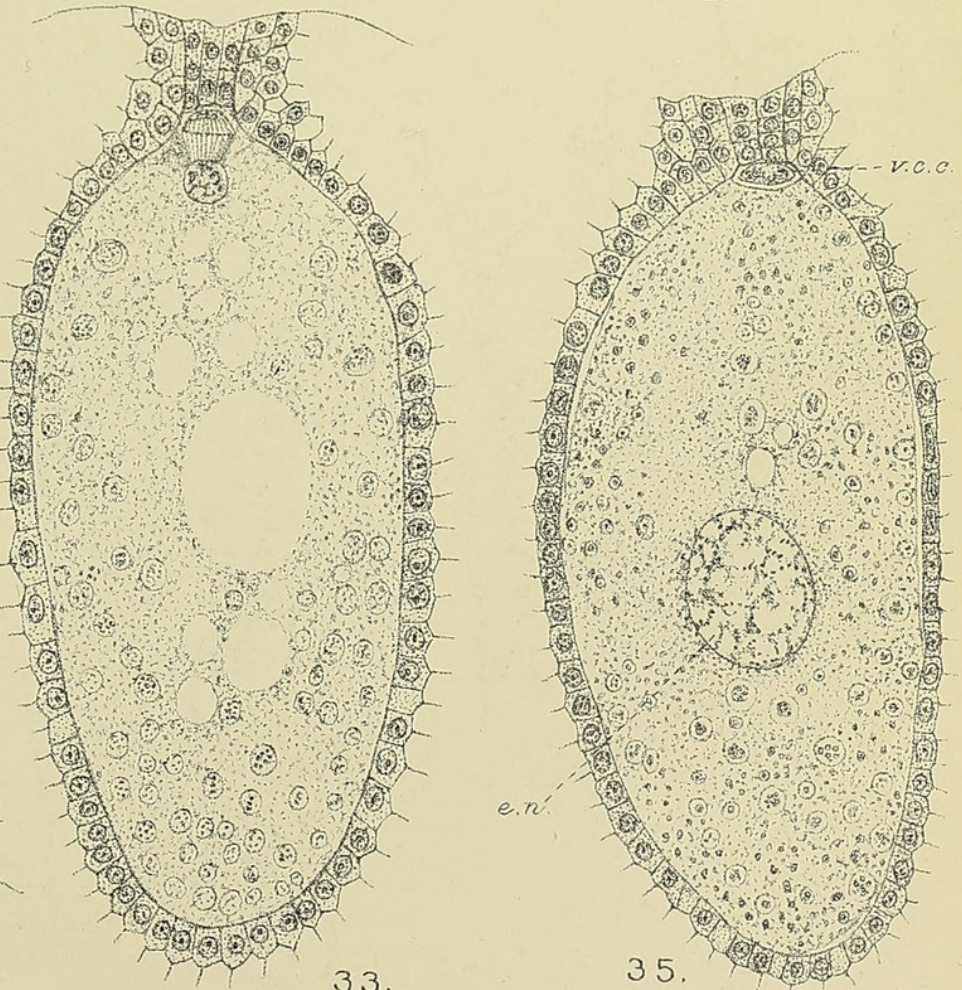

33. 
Annals of Botany.
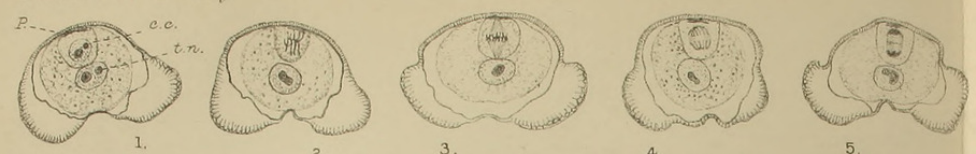

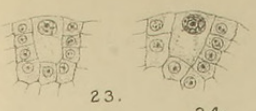

Vol.XVIIPL XVI.
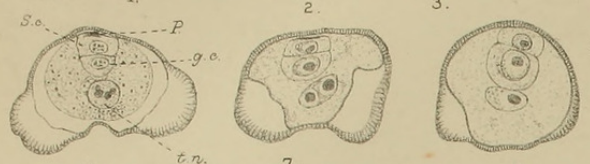

\section{4.}
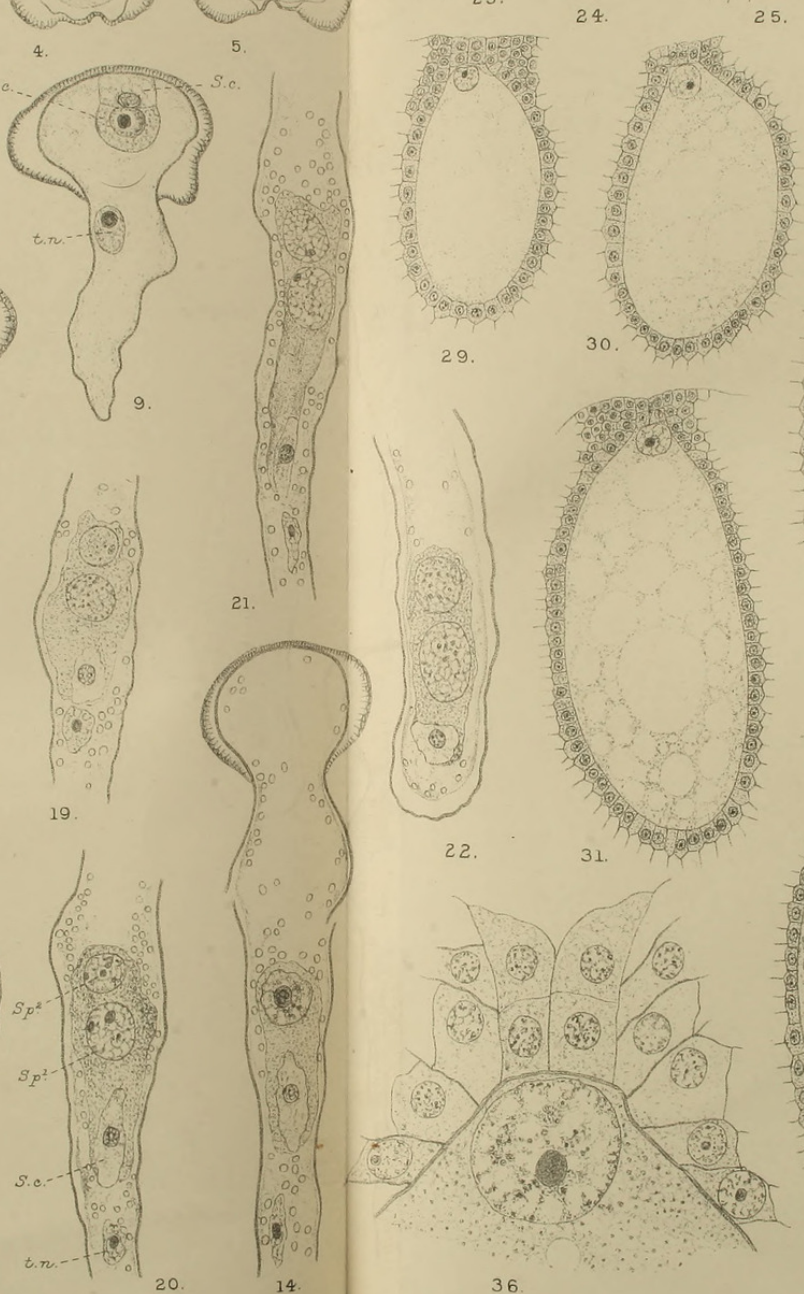

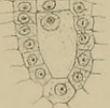

26.

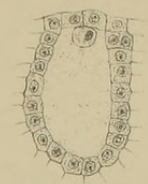

न न

27

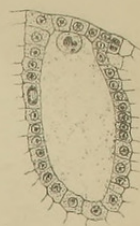

28.

‥ $(0)$
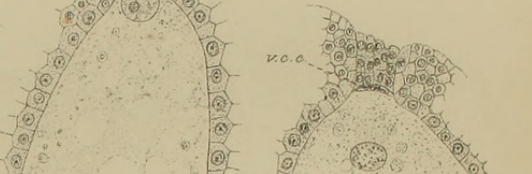

29
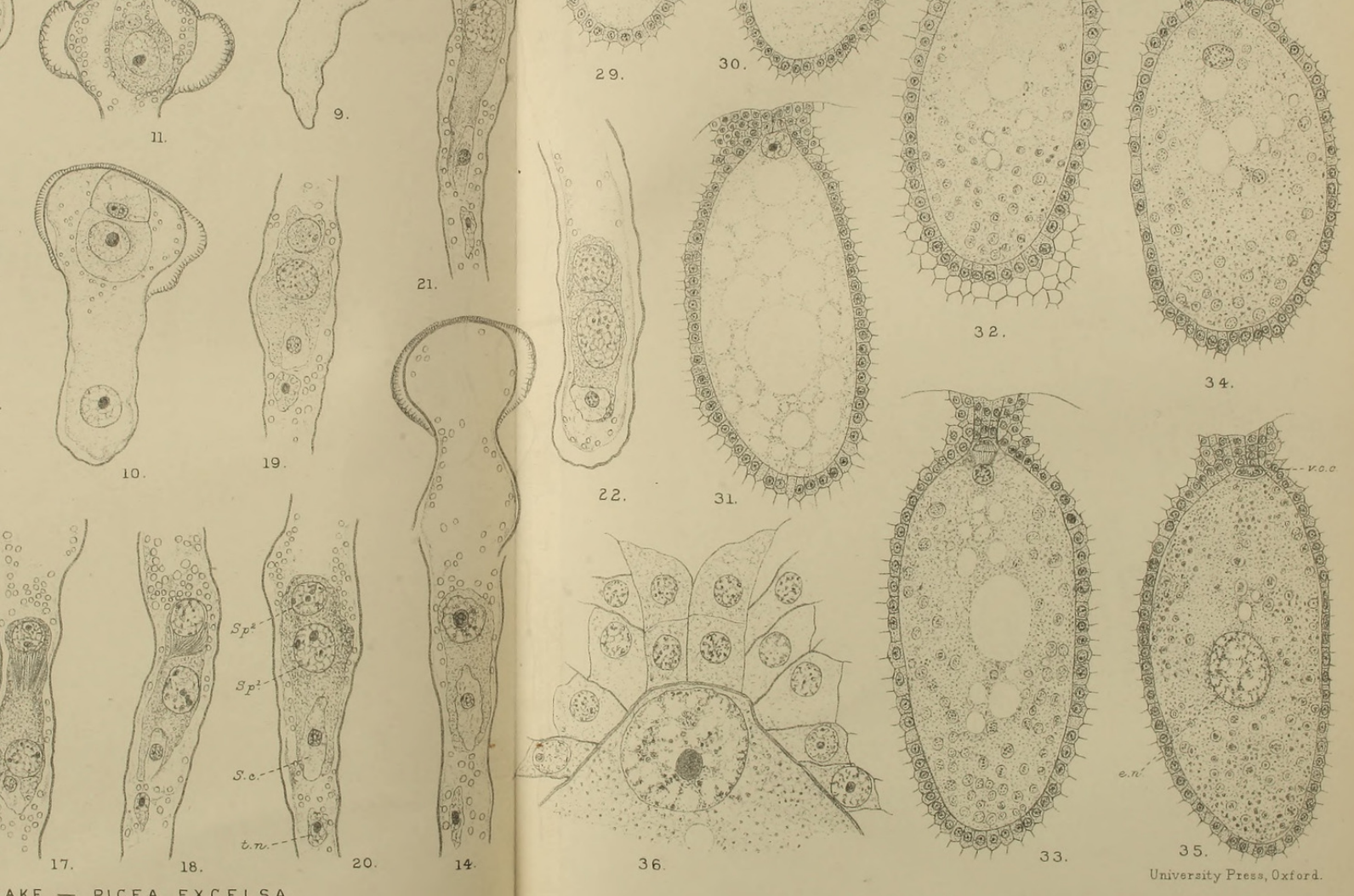

MIYAKE - PICEA EXCELSA. 
Annals of Botany.

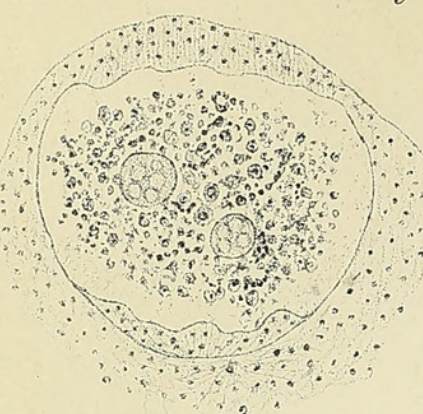

37

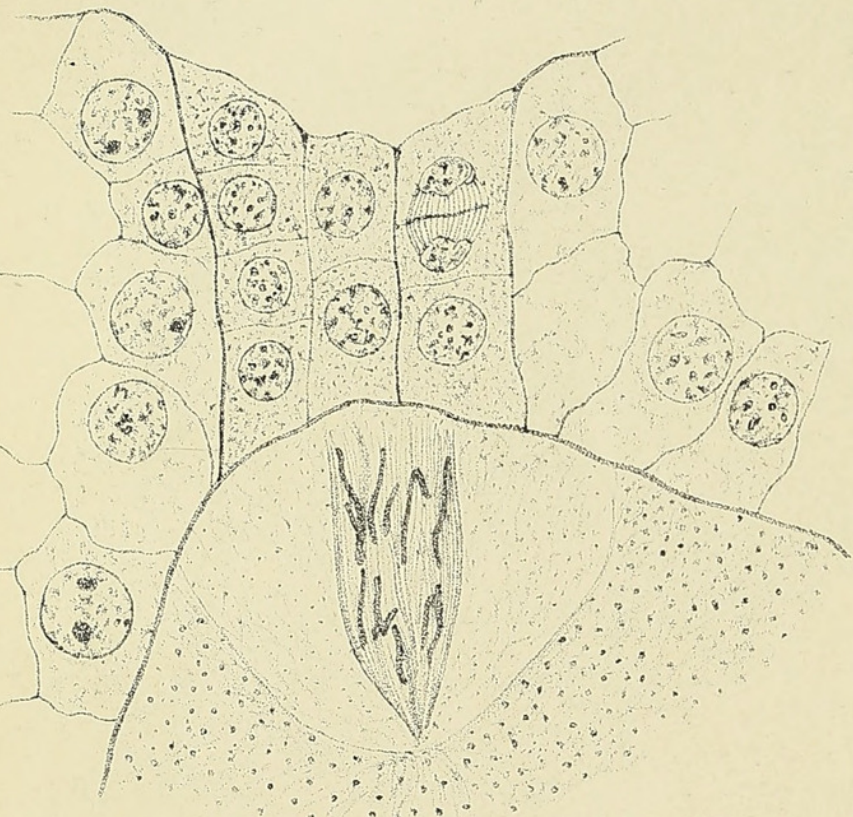

41.
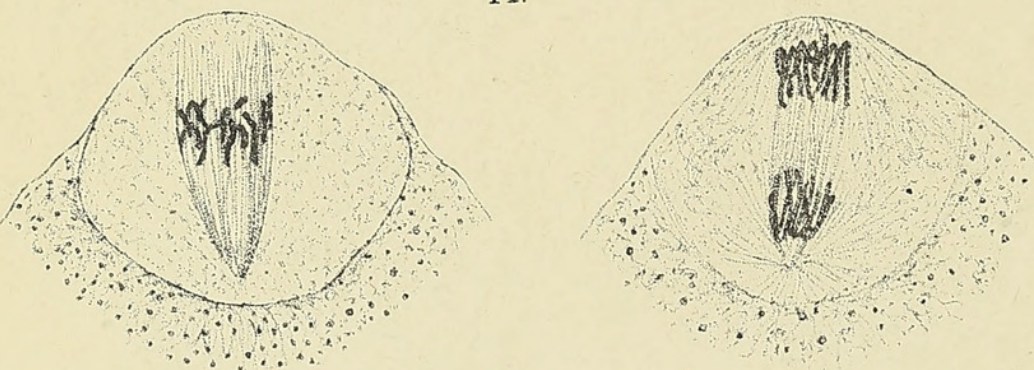

42.

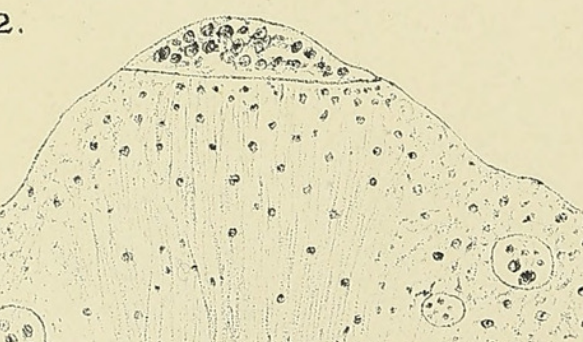

43

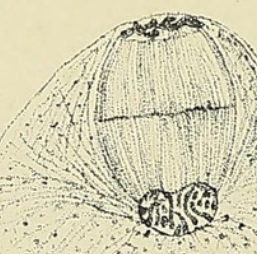

44

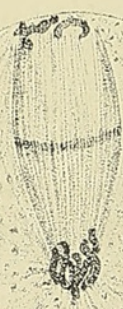

40

39.

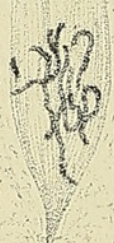

8.e.

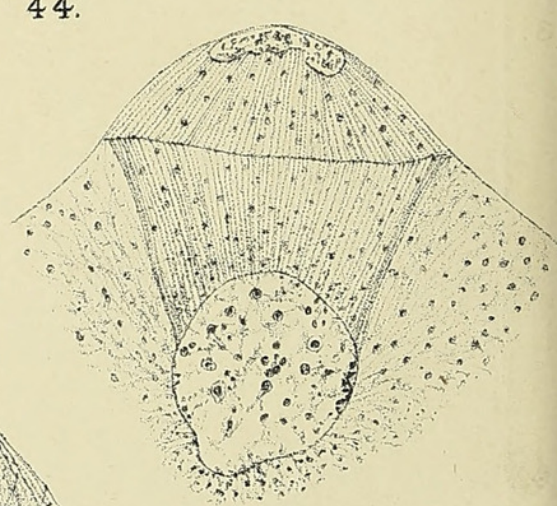

47.

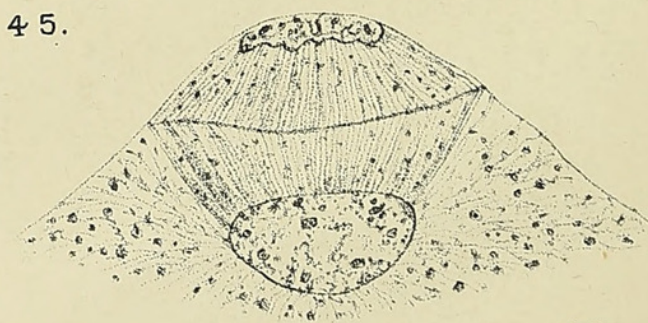

46.

K. Miyake, del. 


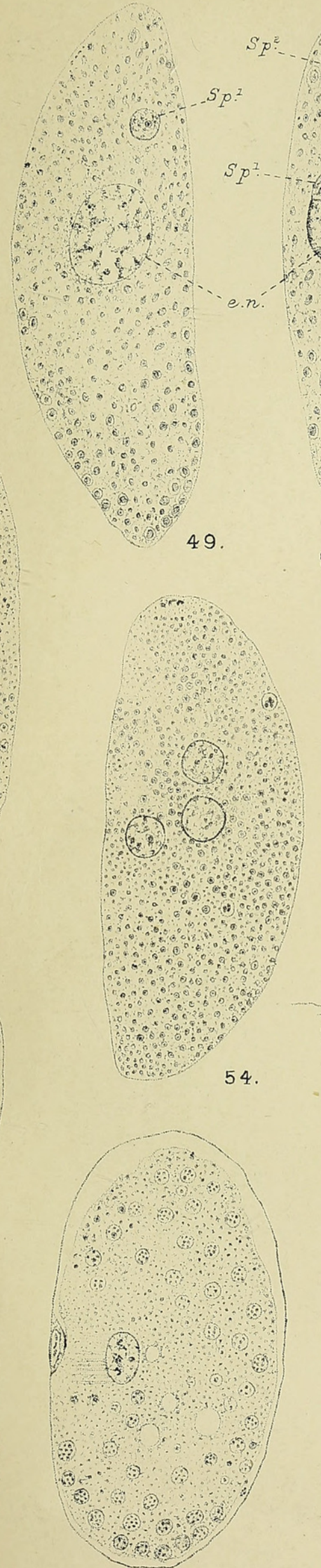

61.

51.

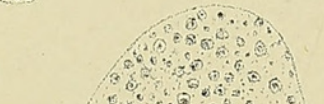


Annals of Botany.
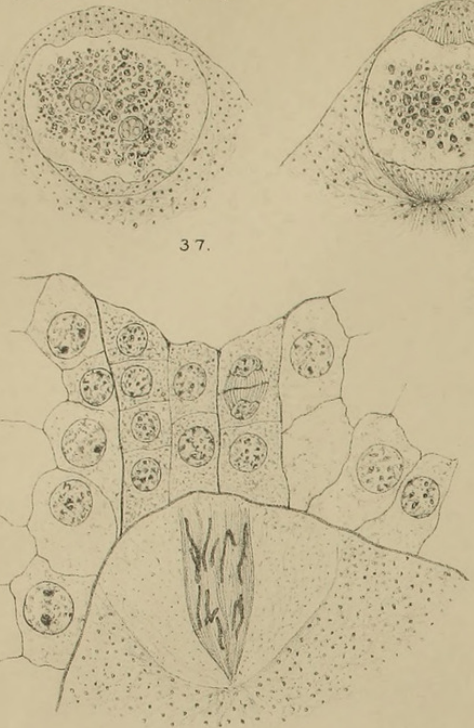

41.

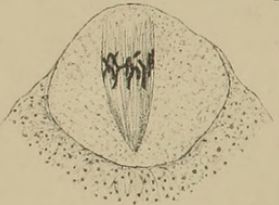

42.
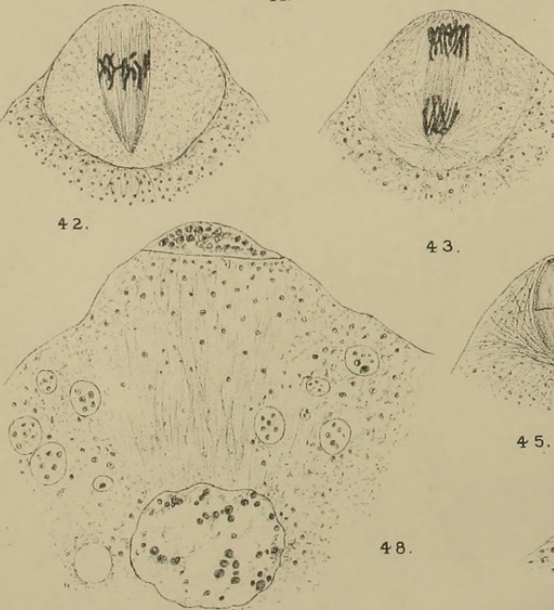

K. Miyake, del.

48
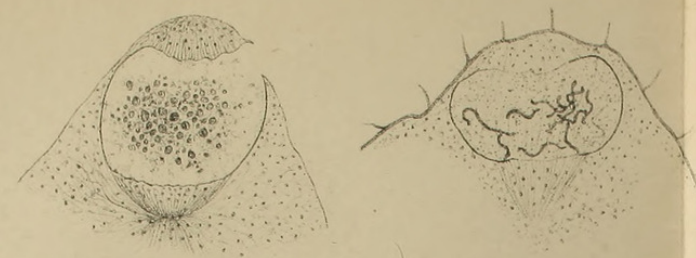

38

39

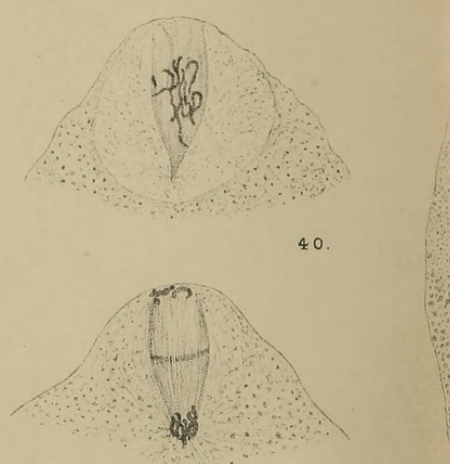

44.

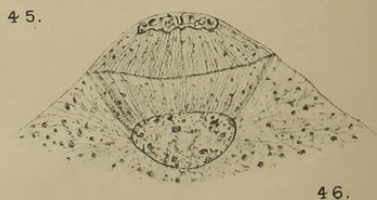

46.
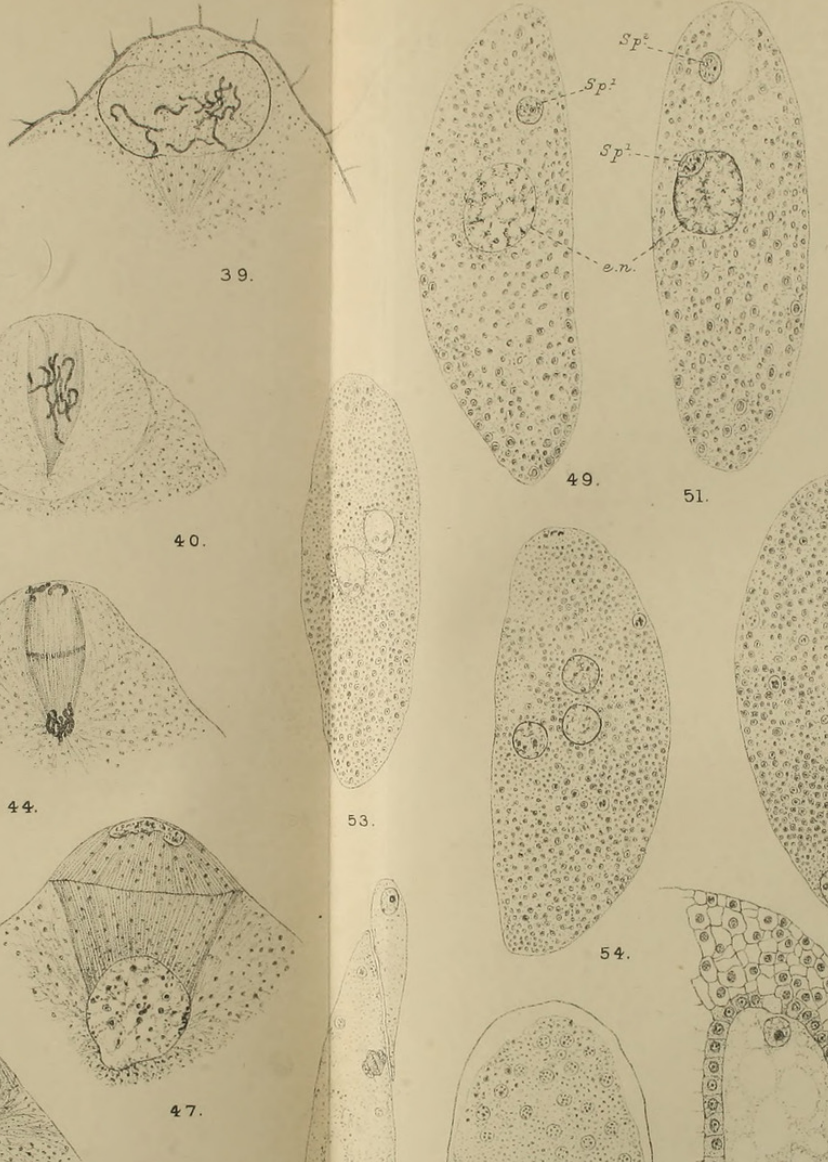

53.

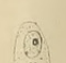

6s:

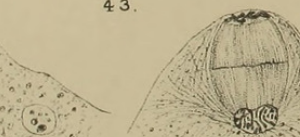

MIYAKE.- PICEA EXCELSA
51.

Vol.XVII,PL.XVII.
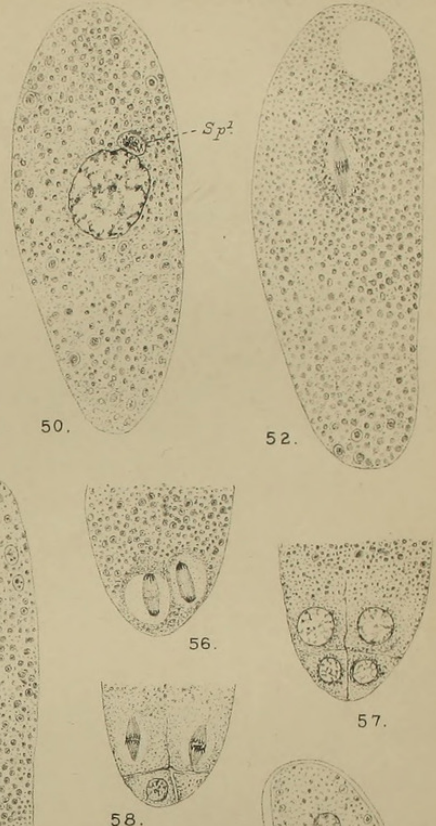

58.

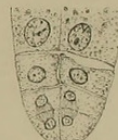

59.

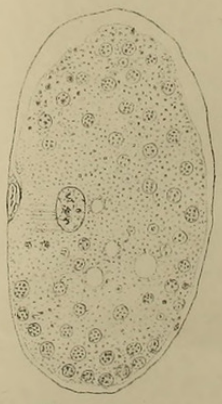

61

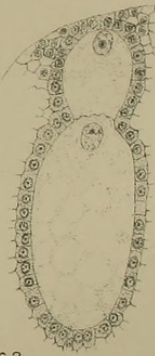




\section{$2 \mathrm{BHL}$ Biodiversity Heritage Library}

Miyake, K. 1903. "On the development of the sexual organs and fertilization in Picea excelsa." Annals of botany 17, 351-372.

https://doi.org/10.1093/oxfordjournals.aob.a088920.

View This Item Online: https://www.biodiversitylibrary.org/item/235015

DOI: https://doi.org/10.1093/oxfordjournals.aob.a088920

Permalink: https://www.biodiversitylibrary.org/partpdf/318718

\section{Holding Institution}

Smithsonian Libraries

\section{Sponsored by}

Biodiversity Heritage Library

\section{Copyright \& Reuse}

Copyright Status: Not in copyright. The BHL knows of no copyright restrictions on this item.

This document was created from content at the Biodiversity Heritage Library, the world's largest open access digital library for biodiversity literature and archives. Visit BHL at https://www.biodiversitylibrary.org. 